Contributions:

A Study design/planning

B Data collection/entry

C Data analysis/statistics

D Data interpretation

E Preparation of manuscript

$F$ Literature analysis/search

$\mathrm{G}$ Funds collection

\title{
TEMPORAL RESOLUTION OF INDIVIDUALS WITH VARYING DEGREES OF ACCEPTABLE NOISE LEVEL
}

\author{
Vipin Ghosh P. G. ${ }^{\text {ACDEF}}$, Hemavathi V. ${ }^{\text {BCEF }}$
}

JSS Institute of Speech and Hearing, Mysore, India

Corresponding author: Vipin Ghosh P. G., JSS Institute of Speech and Hearing, M G Road, Mysore-570004, Karnataka, India, e-mail: vipinghosh78@gmail.com, phone: +91 9844489366

\begin{abstract}
Background: The Acceptable Noise Level (ANL) is a measure of an individual's ability to tolerate background noise while listening to speech. Based on their ANL scores, people can be categorised into 'low', 'mid', or 'high' ANL groups. However, there are reports of subtle central auditory effects on the variation of ANL in normal hearing subjects. Because these reports are based on various objective test findings and interpretations, process-based central auditory testing and subjective authentication is essential in order to understand central involvement in individuals with various degrees of ANL.
\end{abstract}

Methods: A total of 106 Kannada-speaking adults with normal hearing sensitivity participated in the study. Their ANLs were measured and they were then classified into 'low', 'mid', and 'high' groups. The temporal resolution abilities in these participants were tested using the Gap in Noise (GIN) test.

Results: Descriptive analysis along with parametric statistical evaluations were carried out to compare the GIN scores of the three groups. One-way ANOVA revealed that the GIN scores were not statistically different $(p>0.05)$ between the groups.

Conclusions: The result suggests that the temporal resolution of individuals with varying degrees of ANLs is comparable. The absence of temporal resolution difficulties in individuals with varying degrees of ANL do not necessarily contradict earlier reports, as they could have other central auditory processing difficulties. More research is required to clarify these difficulties.

Keywords: temporal resolution $\bullet$ acceptable noise levels $\bullet$ normal hearing sensitivity

\section{HABILIDAD DE RESOLUCIÓN TEMPORAL EN INDIVIDUOS CON DIVERSOS GRADOS DE NIVEL DE RUIDO ACEPTABLE.}

\section{Resumen}

Antecedentes: El nivel de ruido aceptable (Acceptable Noise Level, ANL) es un procedimiento que mide la capacidad de la persona para tolerar el ruido de fondo mientras se escucha un discurso. Estudios anteriores han aceptado que se puede distinguir los grupos de personas con ANL "bajo" "medio" y "alto" dependiendo de su puntuación. Además, se sugiere una influencia auditiva central sutil en la variabilidad de la ANL en personas con audición normal. Estos informes, sin embargo, se basan en varios resultados de investigaciones objetivas y sus interpretaciones. La validación subjetiva y las pruebas basadas en procesos auditivos centrales son esenciales para comprender el impacto de los procesos centrales en personas con diversos grados de ANL.

Métodos: En el estudio participaron 106 hablantes de Kannada con sensibilidad auditiva normal. La ANL de todos los participantes se determinó utilizando la clasificación ANL "baja", "media" y "alta". Las habilidades de resolución temporal de estas personas se analizaron mediante la prueba de Gap in Noise (GIN).

Resultados: Se realizó un análisis descriptivo con evaluaciones estadísticas paramétricas para comparar los resultados de GIN obtenidos en los tres grupos de participantes. Se usó ANOVA unifactorial para el cálculo de la significancia. Los resultados de GIN no fueron estadísticamente significativos ( $\mathrm{p}>0.05)$ entre los grupos.

Conclusiones: El resultado indica que las capacidades de resolución temporal de las personas con diferentes grados de ANL son comparables. La falta de dificultad en la resolución temporal en personas con diversos grados de ANL no necesariamente contradice los informes anteriores, ya que puede haber otros procesos auditivos centrales que pueden verse afectados en tales personas. Se necesitan más investigaciones para explicar las dificultades de procesamiento en personas con diversos ANL.

Palabras clave: resolución temporal • niveles de ruido aceptables • sensibilidad auditiva normal. 


\title{
ВРЕМЕННАЯ РАЗРЕШАЮЩАЯ СПОСОБНОСТЬ У ЛЮДЕЙ С РАЗЛИЧНОЙ СТЕПЕНЬЮ ДОПУСТИМОГО УРОВНЯ ШУМА
}

\begin{abstract}
Аннотация
Введение: Допустимый уровень шума (Acceptable Noise Level, ANL) - это процедура, которая измеряет способность человека переносить фоновый шум во время прослушивания речи. Ранее ученые определили, что можно выделить группы людей с «низким», «средним» и «высоким» ANL. Кроме того, существуют данные о тонком центрально-слуховом влиянии на вариабельность ANL у людей с нормальным слухом. Эти отчеты, однако, основаны на различных объективных результатах исследований и их интерпретациях. Субъективная валидация и исследования, основанные на значениях центральных механизмах слуха, необходимы для понимания влияния центральных механизмов на людей с различной степенью ANL.

Методы: В исследовании приняли участие 106 взрослых носителей языка каннада с нормальной слуховой чувствительностью. ANL для всех участников определяли при помощи классификации «низкий», «средний» и «высокий» ANL. Bременная разрешающая способность этих людей была проанализирована с помощью теста Gap in Noise (GIN).

Результаты: Для сравнения результатов GIN, полученных в трех группах участников, был проведен описательный анализ с параметрическими статистическими оценками. Односторонний анализ ANOVA показал, что результаты GIN статистически не различались ( $>$ > 0,05) между группами.

Выводы: Результаты показывают, что временная разрешающая способность у людей с различной степенью ANL сопоставима. Отсутствие трудностей во временном разрешении у людей с различной степенью ANL не обязательно противоречит предыдущим публикациям, так как у этих людей могут быть нарушены другие центральные слуховые процессы. Необходимы дальнейшие исследования для объяснения трудностей, связанных с этим процессом, у людей с различной степенью восприятия ANL.

Ключевые слова: временное разрешение • допустимые уровни шума • нормальная слуховая чувствительность.
\end{abstract}

\section{ROZDZIELCZOŚĆ CZASOWA U OSÓB O RÓŻNYM STOPNIU POZIOMU AKCEPTOWALNEGO HALASU}

\section{Streszczenie}

Wstęp: Poziom akceptowalnego hałasu (Acceptable Noise Level, ANL) to procedura, która mierzy zdolność osoby do tolerowania szumu w tle podczas słuchania mowy. Wcześniejsi uczeni przyjęli, że można wyodrębnić grupy osób o „niskim”, „średnim” i „wysokim” ANL. Ponadto wskazuje się na występowanie subtelnego centralno-słuchowego wpływu na zmienność ANL u osób z normalnym słuchem. Raporty te są jednak oparte na różnych obiektywnych wynikach badań i ich interpretacjach. Subiektywne uwiarygodnienie i testy bazujące na procesach centralno-słuchowych są niezbędne do zrozumienia wpływu procesów centralnych u osób z różnym stopniem ANL.

Metody: W badaniu wzięło udział 106 dorosłych osób mówiących językiem kannada o normalnej wrażliwości słuchowej. Określono ANL wszystkich uczestników używając klasyfikacji „niski”, „średni” i „wysoki” ANL. Zdolności rozdzielczości czasowej u tych osób była analizowana za pomocą testu Gap in Noise (GIN).

Wyniki: Przeprowadzono analizę opisową z parametrycznymi ocenami statystycznymi w celu porównania wyników GIN uzyskanych w trzech grupach uczestników. Jednoczynnikowa ANOVA pokazała, że wyniki GIN nie były statystycznie różne (p>0,05) między grupami.

Wnioski: Wynik wskazuje, że zdolności rozdzielczości czasowej u osób o różnym stopniu ANL są porównywalne. Brak trudności w rozdzielczości czasowej u osób o różnym stopniu ANL niekoniecznie jest sprzeczny z wcześniejszymi doniesieniami, ponieważ mogą występować inne centralne procesy słuchowe, które mogą być zaburzone u takich osób. Potrzebne są dalsze badania, aby wyjaśnić trudności związane $\mathrm{z}$ tym procesem u osób z różnymi ANL.

Słowa kluczowe: rozdzielczość czasowa • akceptowalne poziomy hałasu • normalna wrażliwość słuchowa

\section{Background}

The Acceptable Noise Level (ANL) is a procedure to measure an individual's ability to tolerate background noise while listening to speech[1]. This quick and simple procedure has made ANL a clinically viable tool. Various researchers have attempted to distinguish the ANL in normal hearing individuals from that in individuals with hearing impairment or related disorders. One such study[2] sought to understand the distribution of ANLs in individuals with hearing impairment. Based on their findings, they categorized participants into 'low', 'mid', and 'high' ANL groups. The low ANL group had ANLs of less than $7 \mathrm{~dB}$, mid ANL had ANLs of 7-13 dB, and high ANL had levels greater than $13 \mathrm{~dB}$. They also reported that individuals with low ANLs were generally successful hearing-aid wearers, whereas individuals with high ANLs were largely unsuccessful in wearing hearing aids. People with mid ANLs may or may not be successful with hearing aids. A similar tendency towards low, mid, or high ANL has been reported in individuals with normal hearing sensitivity[3].

Additional research has been done to explore this difference in ANL among individuals with hearing impairment and normal hearing sensitivity. Efforts have been made[3] to measure physiological responses such as click-evoked otoacoustic emissions (CEOAEs), auditory brainstem responses (ABRs), and middle latency responses (MLRs) in females with normal hearing with low $(n=6)$ versus high $(n=7)$ ANLs. The results indicated no differences between individuals with low and high ANLs for CEOAEs or waves I or III of the ABR. Differences between the two groups emerged for wave $\mathrm{V}$ of the $\mathrm{ABR}$ and $\mathrm{Na}-\mathrm{Pa}$ of the 
MLR. These results support the hypothesis that acceptance of background noise is mediated from central regions of the auditory system.

Further investigations have included cortical evoked potentials. In addition to ABRs and MLRs, auditory long latency responses (LLRs) have been obtained from two groups of females: one with low ANLs and one with high. ANLs were measured at three speech presentation levels (35 dB HL, MCL (most comfortable level), and 70 $\mathrm{dB} H \mathrm{~L}$ ) for the two listener groups. Results revealed no differences between the two groups for the early waves of the ABR, but significant differences existed between the two groups for waves III and V of the ABR and for the MLR and LLR peaks. This further supports central involvement in determining an individual's ANL. It is also reported that this variability in ANL is not related to age, gender [5], hearing sensitivity, speech perception in noise, type of background noise [6], middle ear characteristics [7], or efferent activity of the medial olivocochlear pathway $[6,2]$.

Precise temporal processing abilities are required to perceive and process the temporal aspects of a signal in order for it to be perceived in quiet as well as noisy situations. Auditory temporal processing is defined as the ability to perceive the temporal envelope or the variation in duration of a sound within a defined time interval [8]. Temporal processing may be conceptualized as four sub processes: temporal resolution, temporal patterning, temporal integration, and temporal masking [9]. Temporal processing is an important auditory skill that is necessary for higher level auditory processing. Although, the temporal processing abilities of individuals with varying ANLs are not understood, subtle differences in temporal processing abilities may be suspected, since dissimilar sub-cortical and cortical electrophysiological responses have already been reported. Moreover, earlier explanations of variation in ANL were all based on objective evaluations. An account based on subjective evaluations has not yet been documented. Hence, the present study assesses the temporal resolution of individuals with normal hearing sensitivity who have different degrees of ANL.

\section{Materials and Methods}

\section{Participants}

A total of 106 native Kannada speakers began the study. All subjects were aged 18-40 years. After excluding 6 participants who exhibited some middle ear dysfunction and hearing loss, 100 participants with normal hearing sensitivity and middle ear functioning (58 males and $42 \mathrm{fe}-$ males) were enrolled for further testing.

\section{Procedure}

A detailed case history was taken prior to testing to rule out any otological complaints. All participants underwent pure tone audiometry and immittance evaluation prior to the ANL and temporal resolution assessment. A calibrated two-channel Inventis Piano diagnostic audiometer connected to TDH-39 headphones and Radio Ear 71 bone vibrator was used to measure air conduction and bone conduction thresholds. The same audiometer was used to find the uncomfortable level of all the participants. A calibrated Inventis Clarinet immitance meter was used for tympanometry and reflexometry.

The 100 participants who passed the screening then underwent ANL testing. The standard procedure suggested by earlier experiments was followed [1]. The speech stimulus used for ANL measurement was a standardised Kannada story. The story was spoken in a normal effort by a native Kannada female speaker which was recorded onto a computer; the background noise was speech-shaped noise. Both speech stimulus and noise were presented through a custom application in Matlab. Calibrated headphones were used to present the speech stimulus and noise binaurally to each participant. To establish ANL, the most comfortable level (MCL) of the participant was determined, followed by the background noise level (BNL).

In order to identify MCL, the subjects were asked to listen to a story through headphones. The loudness of the running speech was at $0 \mathrm{~dB} \mathrm{HL}$ at the beginning and was increased in steps of $10 \mathrm{~dB}$ until the listener indicated that it was "too loud" and then the loudness was decreased in $10 \mathrm{~dB}$ until the listener indicated that it was "too soft". At this point, the level of the story was adjusted up and down in $5 \mathrm{~dB}$ increments until the listener indicated the most comfortable loudness, which was considered as MCL.

Once the participant's MCL was established, the speech was continued at that level while the background noise was added to establish the background noise level (BNL). The loudness level of the noise was set at $0 \mathrm{~dB} \mathrm{HL}$ at the beginning and then increased in $5 \mathrm{~dB}$ steps until the listener indicated that the noise was "too loud" to accept while following the story; the loudness of the noise was then decreased in $5 \mathrm{~dB}$ steps until the listener indicated that the noise was "too soft" to accept while following the story. At this point, the level of the noise was adjusted up and down in $1 \mathrm{~dB}$ increments until the listener indicated it was the highest level that could be accepted while following the story without becoming tense or tired. This level was considered as the participant's BNL. The ANL was calculated by subtracting the BNL from the MCL $(\mathrm{ANL}=\mathrm{MCL}-\mathrm{BNL})$. The MCL and BNL procedures were repeated three times, and the average of the three ANLs was considered.

Out of the 100 individuals who underwent ANL testing, 54 subjects had a low ANL score $(<7 \mathrm{~dB}), 28$ subjects had mid ANL score (7-13 dB), and 15 subjects had high ANL score (>13). 15 individuals were randomly selected from each of these groups for further evaluations in order to maintain uniformity. All these 45 participants further underwent temporal resolution testing using the Gap in Noise (GIN) test. GIN measures the ability of the auditory system to perceive a small temporal gap in an ongoing auditory signal.

A broadband noise signal of $500 \mathrm{~ms}$ in duration was used as the stimulus. Noise was used for the GIN test, as its magnitude spectrum does not change when a gap is inserted. 
Table 1. Mean and standard deviation of ANL obtained in 3 groups

\begin{tabular}{cccc}
\hline ANL groups & $\boldsymbol{n}$ & Mean (dB) & $\begin{array}{c}\text { Standard } \\
\text { deviation } \\
(\mathbf{d B})\end{array}$ \\
\hline Low $(<7 \mathrm{~dB})$ & 54 & 3.66 & 2.19 \\
\hline Mid $(7-13 \mathrm{~dB})$ & 28 & 9.60 & 1.88 \\
\hline High $(>13 \mathrm{~dB})$ & 15 & 16.86 & 3.87 \\
\hline
\end{tabular}

Table 2. Mean and standard deviation of GIN scores obtained in Low, Mid, and High ANL groups

\begin{tabular}{cccc}
\hline Groups & $\boldsymbol{n}$ & $\begin{array}{c}\text { Mean } \\
(\mathbf{m s})\end{array}$ & $\begin{array}{c}\text { Standard } \\
\text { deviation } \\
(\mathbf{m s})\end{array}$ \\
\hline Low $(<7 \mathrm{~dB})$ & 15 & 2.65 & 0.64 \\
\hline Mid $(7-13 \mathrm{~dB})$ & 15 & 2.69 & 0.57 \\
\hline High $(>13 \mathrm{~dB})$ & 15 & 2.66 & 0.50 \\
\hline
\end{tabular}

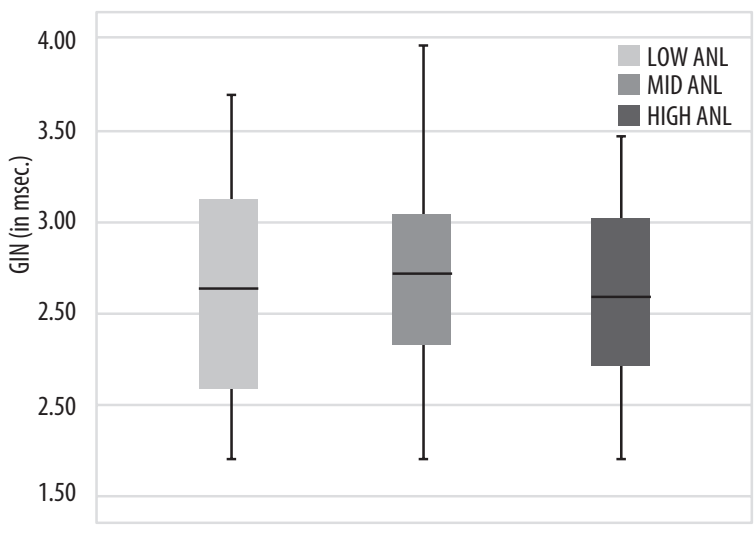

GROUPS

Figure 1. Median GIN scores of all three groups

The noise had $0.5 \mathrm{~ms}$ cosine ramps at the beginning and end of the gap to avoid abrupt changes in the noise spectrum which might aid the listeners in gap detection. The minimum duration of the gap was $0.1 \mathrm{~ms}$ and the maximum was $64 \mathrm{~ms}$. The GIN test was administered by adapting the procedure suggested in the literature [10], with the gap positioned at the temporal center of the noise. The initial duration of the gap was $42.24 \mathrm{~ms}$. A practice trial was done before testing began to make sure that the subject understood the instructions and mode of response. The entire testing was carried out using the maximum likelihood procedure (MLP) which was programmed in Matlab [11]. In MLP, the psychometric functions of a large number of candidates are estimated and the probability of the participant's response to each stimulus (compared to that of the psychometric function) is calculated. Each test trial lasted for around 5 to 6 minutes which, along with practice trial and instructions, added up to approximately 10 minutes. The stimulus was presented using a Lenovo laptop (Intel i7 processor) equipped with Sennheieser HD 202 headphones. The intensity of the stimulus was maintained at the participant's most comfortable level of loudness. Stimuli during the entire testing were presented binaurally to all participants.

A total of 30 trials were presented to each participant. A three-alternative forced choice procedure (3-AFC) was used for stimulus presentation. In each 3-AFC trial, three stimuli were presented, with a temporal gap in one of the stimuli (a variable stimulus) and no gap in the remaining two (the standard stimulus). The participants were asked to identify and tell the position of the variable stimulus. The duration of the temporal gap increased or decreased adaptively on the basis of the response for the previous trial. The responses were recorded in the MLP toolbox. The minimum gap in the variable stimulus which the participant was able to identify was considered the gap-in-noise threshold. A 3 up - 1 down procedure was used to confirm the reliability of the response. The threshold for each individual was tabulated for further statistical analysis.

\section{Results}

Descriptive statistics were carried out initially to find the mean and standard deviation (SD) of the ANL in each group. This information is given in Table 1 .

The mean and standard deviation of GIN scores obtained by the participants in each group were also obtained and are given in Table 2. Box-plots depicting the median GIN scores of all three groups are given in Figure 1.

From Figure 1 it is clear that the mean GIN scores were similar in all three groups. However, to check for the statistical significance of this result further analysis was carried out. A Shapiro Wilk test showed that the data followed a normal distribution, and a parametric statistical analysis was then carried out. A one-way ANOVA showed there was no significant difference in mean GIN scores between the groups $(F=0.02, p>0.05)$.

\section{Discussion}

The temporal resolution ability of individuals with varying degrees of ANL was assessed using the GIN test. GIN scores were obtained for all participants in the 3 groups with varying ANLs and the mean scores were compared across the groups. The results revealed that there was no significant difference in GIN scores between the groups. This suggests an absence of temporal resolution difficulties which is an aspect of central auditory processing in individuals with high ANL. It is also interesting that the GIN scores obtained in all three groups were better than the general trend reported in the literature. Earlier researchers have already demonstrated the effect of stimulus level on GIN thresholds: as the level of presentation increases, GIN thresholds also improve until around $50 \mathrm{~dB}$ SL [12]. The current study employed GIN testing at the most 
comfortable level of the subjects. This methodological deviation might have resulted in a better GIN threshold observed in all three groups in the present study.

This finding may seemingly contradict earlier research since a central auditory processing anomaly is reported in individuals with high ANL. To understand the auditory related issues in individuals with high ANL, former attempts have included the study of click-evoked otoacoustic emissions (CEOAEs), auditory brainstem responses (ABRs), and middle latency responses (MLRs) in females with normal hearing who had low versus high ANLs [3]. The study found that OAEs and the earlier peaks of the $\mathrm{ABR}$ were similar between the groups.

However, later peaks of ABR and MLR responses were deviant in individuals with high ANL. Hence, as the responses from the central auditory segments were deviant in individuals with high ANLs, they suggest a probable central auditory processing disparity in individuals with varying degrees of ANLs. In addition to ABR and MLR assessment in females with low and high ANL, further research [4] has investigated cortical electrophysiological responses (which includes LLR): this work also points to central auditory deficits, as the later peaks of ABR and MLR and LLR peaks were deviant in the high ANL group but not in the low ANL group.

The current study has used subjective tests to assess the temporal resolution ability of individuals with varying degrees of ANLs, recognising that the GIN test is reported to be a clinically useful tool in the assessment of temporal resolution [8] and that temporal resolution ability is one of the various central auditory abilities.

Testing for temporal resolution ability has been used to assess auditory processing in various hearing-related disorders such as tinnitus [13-16] and in participants who have been exposed to occupational noise $[17,18]$. The tinnitus findings suggest that temporal resolution is affected in individuals with the complaint. However, such a deficit is not seen in normal hearing individuals who are exposed to occupational noise. Thus, tests for temporal resolution prove to be a widely available and affordable way for examining one aspect of auditory processing in humans. However, an absence of difficulty in one aspect does not warrant the precision of other processes. Thus, the absence of temporal resolution difficulties in individuals with varying degrees of ANL does not necessarily contradict the earlier reports, as there may be other central auditory processes that may be affected in such individuals. However, these alternative processes were not considered in the present study.

\section{Conclusion}

The present study was conducted to investigate the temporal resolution abilities of individuals with varying ANL. The results of the study suggest that these abilities are similar in all groups with different ANL, whether low or high. Although there are earlier reports of central involvement in individuals with higher ANL, it is not reflected in the temporal resolution abilities of the individuals we studied. Nevertheless, there are other central auditory processes which were not examined in the present study. A battery of central auditory processing evaluations may thus help in understanding the process-specific deficits that such individuals may exhibit.

\section{Acknowledgments}

The authors acknowledge the Director, JSS Institute of Speech and Hearing, for permission to carry out the study. Sincere gratitude to all the participants.

\section{References}

1. Nabelek AK, Tucker FM, Letowski TR. Toleration of background noises: relationship with patterns of hearing aid use by elderly persons. J Speech Hear Res, 1991; 34: 679-85.

2. Nabelek AK, Tampas JW, Burchfield SB. Comparison of speech perception in background noise with acceptance of background in aided and unaided conditions. J Speech Hear Res, 2004; 47: 1001-11.

3. Harkrider AW, Tampas JW. Differences in responses from the cochleae and central nervous systems of females with low versus high acceptable noise levels. J Am Acad Audiol, 2006; 17: 667-76.

4. Tampas JW, Harkrider AW. Auditory evoked potentials in females with high and low acceptance of background noise when listening to speech. J Acoust Soc Am, 2006; 119(3): 1548-61.

5. Rogers DS, Harkrider AW, Burchfield SB, Nabelek AK. The influence of listener's gender on the acceptance of background noise. J Am Acad Audiol, 2003; 14: 374-85.

6. Crowley HJ, Nabelek IV. Estimation of client-assessed hearing aid performance based upon unaided variables. J Speech Lang Hear Res, 1996; 39: 19-27.

7. Harkrider AW, Smith B. Acceptable noise level, phoneme recognition in noise, and auditory efferent measures. J Am Acad Audiol, 2005; 16: 530-45.
8. Musiek FE, Shinn JB, Jirsa R, Bamiou DE, Baran JA, Zaida E. GIN (Gaps-In-Noise) test performance in subjects with confirmed central auditory nervous system involvement. Ear Hear, 2005; 26(6): 608-18.

9. Shinn JB. Temporal processing and temporal patterning tests. In: Handbook of (Central) Auditory Processing Disorder: Auditory neuroscience and diagnosis. Vol. 1. San Diego, Plural Publishing; 2007. pp. 231-56.

10. Harris KC, Eckert MA, Ahlstrom JB, Dubno JR. Age-related differences in gap detection: effects of task difficulty and cognitive ability. Hear Res, 2010; 264: 21-9.

11. Grassi M, Soranzo A. MLP: a MATLAB toolbox for rapid and reliable auditory threshold estimation. Behav Res Methods, 2009; 41(1): 20-8.

12. Weihing JS, Musiek FE, Shinn JB. The effect of presentation level on the Gap-In-Noise (GIN) test. J Am Acad Audiol, 2007; 18: 141-50.

13. Jain S, Dwarkanath VM. Effect of tinnitus location on the psychoacoustic measures of hearing. Hear Bal Commun, 2016; 14(1): 8-19.

14. Fournier P, Héber S. (2013). Gap detection deficits in humans with tinnitus as assessed with the acoustic startle paradigm: Does tinnitus fill in the gap? Hear Res2013; 295: 16-23. https://doi. org/10.1016/j.heares.2012.05.011 
15. Sanches SGG, Samelli AG, Nishiyama AK, Sanchez TG, Carvallo RMM. GIN test (Gaps-in-Noise) in normal listeners with and without tinnitus. Pro Fono, 2010; 22(3): 257-62.

16. Vahid MG, Masumeh R, Parvane M, Amin A, Mohammad HNK, Jalal S, Alireza KY, Hamed E. Temporal processing evaluation in tinnitus patients: results on analysis of gap in noise and duration pattern test. Iran J Otorhinolaryngol, 2013; 25(73): 221-6.

17. Kumar A, Syed KA, Sangamanatha AV. Temporal and speech processing skills in normal hearing individuals exposed to occupational noise. Noise Health, 2012; 14: 100-5.

18. Vipin G, Sharmada K, Meera RA. Effect of long-term exposure to traffic noise on auditory temporal resolution of traffic police: a preliminary study. J Hear Sci, 2016; 6(4): 50-4. 